Review Article

\title{
Physical and Chemical Properties, Pretreatment, and Recycling of Municipal Solid Waste Incineration Fly Ash and Bottom Ash for Highway Engineering: A Literature Review
}

\author{
Yong Lu, ${ }^{1,2}$ Angran Tian, ${ }^{3}$ Junhui Zhang, ${ }^{4}$ Yongsheng Tang, ${ }^{5}$ Peixin Shi, ${ }^{3}$ \\ Qiang Tang, ${ }^{3,4}$ and Yucheng Huang $\mathbb{1}^{3}$ \\ ${ }^{1}$ JSTI Group, Nanjing 211112, China \\ ${ }^{2}$ National Engineering Laboratory for Advanced Road Materials, Nanjing 211112, China \\ ${ }^{3}$ School of Rail Transportation, Soochow University, Suzhou 215131, China \\ ${ }^{4}$ National Engineering Laboratory of Highway Maintenance Technology, Changsha University of Science \& Technology, \\ Changsha 410114, China \\ ${ }^{5}$ College of Civil and Transportation Engineering, Hohai University, Nanjing 210098, China
}

Correspondence should be addressed to Yucheng Huang; ychuang@suda.edu.cn

Received 18 September 2020; Revised 5 November 2020; Accepted 15 November 2020; Published 9 December 2020

Academic Editor: Zhigang Zhang

Copyright $\odot 2020$ Yong Lu et al. This is an open access article distributed under the Creative Commons Attribution License, which permits unrestricted use, distribution, and reproduction in any medium, provided the original work is properly cited.

\begin{abstract}
Municipal solid waste incineration (MSWI) has been widely used due to its benefits in reducing waste and recovering energy. However, MSWI fly ash and bottom ash are increasing rapidly, causing harm to human health and the environment. This paper discussed the production process, physical and chemical properties, leaching properties, pretreatment methods, and applications of fly ash and bottom ash. By summarizing the previous literature, it is found that MSWI fly ash and bottom ash have mechanical properties similar to natural aggregate. Many beneficial attempts have been made in cement concrete aggregates, ceramic raw materials, and highway engineering materials. Due to concerns about the leaching of heavy metals in fly ash, its application in highway engineering is limited. The application of bottom ash in asphalt pavement is rare because of the side effect on the performance of asphalt mixture. Considering the solidification effect of cement on heavy metals and the low cost of fly ash and bottom ash, the application in cement-stabilized macadam base has broad application prospects. This is beneficial to reduce the construction cost and promote the process of waste incineration, especially in developing countries.
\end{abstract}

\section{Introduction}

With the development of economy and the process of urbanization, more than 20 billion tons of municipal solid waste (MSW) is generated in the world every year. According to estimates, about 34 billion tons of MSW will be produced in 2050 [1-4]. However, 33\% of them are not harmlessly treated, especially in low-income and middleincome countries [5-7]. If MSW could not be dealt with in an ecofriendly manner, it will cause many social and environmental problems, such as occupying valuable urban area, generating harmful bacteria, viruses, and other microorganisms, and polluting the surrounding environment
[8-10]. What's worse, the toxic substances are able to spread to the atmosphere and groundwater by wind or rain and even cause a huge impact on the global ecological environment.

The main treatment methods to treat MSW include landfill, composting, and incineration [11-13]. Landfill is to build isolation facilities underground or ground to separate the MSW from the surrounding environment. This is a lowcost and low-tech processing method [14]. However, the quantity of MSW has far exceeded the capacity of landfills. Furthermore, if the waste is not harmlessly treated, the remaining bacteria, viruses, heavy metals, and other pollutants will exist for a long time and may pollute the 
surrounding environment $[15,16]$. Composting refers to the treatment of degradable organic waste by biochemical technology [17-19]. The organics in the MSW are decomposed and converted into stable soil humus. The types of composting can be roughly divided into anaerobic fermentation and aerobic fermentation [20,21]. The process can decompose organics to produce carbon dioxide, water, methane, and soil humus. Composting is suitable for the treatment with high content of perishable organics, and its investment is much lower than that of incineration. However, composting cannot deal with nonperishable organic and inorganic substances [22, 23]. Municipal solid waste incineration (MSWI) refers to reduce the volume of waste through proper thermal decomposition, combustion, melting, and other reactions. The heat of incineration can be used to generate electricity. However, improper control of incineration conditions will cause air pollution [24-26].

Comprehensively comparing the abovementioned methods, MSWI has become more extensive because of its advantages in reducing the amount of garbage, reducing environmental pollution, and recycling energy [27, 28]. However, fly ash and bottom ash are produced in large quantities caused by incomplete combustion of MSW. Among them, fly ash accounts for about $2.5 \%$, and bottom ash accounts for about 7.5\%. According to estimation, more than 500 million tons of fly ash and 1.5 billion tons of bottom ash are produced every year [29]. With the increase of MSWI, these by-products will soon have no place to store and can only be piled up or landfilled at will, which will take up land resources. What's more, after incineration, heavy metals still remain in fly ash and bottom ash. When they enter into soil or water, the environment will be polluted and people's health will be threatened [30, 31].

Fly ash and bottom ash have potential to be reused in many ways. If treated by appropriate methods, the economic and ecological benefits can be achieved. Fly ash contains many toxic substances, and the leaching of some heavy metals exceeds the relevant standards $[32,33]$. Therefore, it must be harmless before direct landfill or utilization. The pretreatment methods of fly ash mainly include separating, solidification/stabilization, and heat treatment [34-36]. Considering its good strength, fly ash can be used as building materials, as the aggregate of cement concrete, asphalt concrete, or ceramics [37-40]. Due to its adsorption ability, fly ash can also be used to make adsorption materials to purify industrial or agricultural waste water. Bottom ash is less toxic and can be directly reused. The benefits obtained by these methods are different; hence, they need to be selected according to the characteristic of the bottom ash and the recycling method. The recycling methods of bottom ash mainly include cement concrete aggregates, asphalt concrete aggregates, ceramic materials, bricks, and other materials [41-45].

This paper mainly summarizes the physical and mechanical properties, leaching characteristics, and pretreatment methods of MSWI fly ash and bottom ash and discusses the utilization. What's more, the applications and of MSWI fly ash and bottom ash are studied to promote further utilization, especially in highway engineering.

\section{MSWI Process}

MSWI mainly includes the following steps: waste storage, waste incineration, waste heat power generation, flue gas treatment, waste leachate treatment, and by-products treatment [46-49]. The MSWI process is shown in Figure 1.

The harmful and incombustible substances in MSW are picked out. The remaining MSW is put into the waste storage pool after weighing. The MSW in the storage must be stirred and crushed to make sure the even distribution, and the leachate generated in the process should be collected to avoid polluting the environment [50-52].

After the storage process, MSW is sent into the incinerator through the related equipment, and the waste incineration begins. After the waste is burned, bottom ash is generated, and it must be cleaned up regularly. The incinerator is divided into a grate furnace, circulating fluidized bed furnace, and grate furnace with different incineration methods [53, 54]. Waste incineration power generation technology also has two types of equipment, waste heat boilers and steam turbine generators. After the waste is incinerated in the incinerator, the heat generated by the waste heat boiler is converted into steam, which can be used by the turbogenerator to generate electricity.

MSWI produces many harmful substances such as heavy metal, dioxin, smoke dust, and so on. If these harmful substances cannot be handled well, they will cause secondary pollution to the environment $[55,56]$. The flue gas needs to be purified by different types of reaction towers.

After the incinerator burns MSWI, fly ash and bottom ash are collected. The treated by-products can be used as a material for making bricks, building materials, and pavement materials. The fly ash must be treated in a harmless manner before it is landfilled.

\section{Physicochemical and Leaching Properties}

3.1. Physicochemical Properties. MSWI fly ash is gray or dark gray with an irregular structure [57]. The particle size of fly ash is larger than that of cement, and its density is about $1.5-2.4 \mathrm{~g} / \mathrm{cm}^{3}$ [58]. The particle size distribution is shown in Figure 2. MSWI fly ash has a high porosity and adsorption, and some volatile heavy metals are adsorbed on the surface of MSWI fly ash [59].

Due to the influence of the waste source, incineration mode, and purification system, the composition of fly ash is quite different. At higher temperature, the loss on ignition is about $13 \%$ [60]. Fly ash is mainly composed of $\mathrm{Ca}, \mathrm{Si}, \mathrm{Al}, \mathrm{Fe}$, and other elements, and the main components are $\mathrm{SiO}_{2}$, $\mathrm{CaO}, \mathrm{Al}_{2} \mathrm{O}_{3}, \mathrm{~N}_{\mathrm{a}} 2 \mathrm{O}$, and $\mathrm{K}_{2} \mathrm{O}$, as shown in Table 1 [61-64]. Because it contains some soluble salts, its composition will change after washing. In addition, fly ash also contains heavy metals, such as $\mathrm{Zn}, \mathrm{Pb}, \mathrm{Cr}, \mathrm{Cu}$, and others.

MSWI bottom ash is a mainly spherical structure, which varies with different physical composition, and its density varies in the range of $1.4-1.8 \mathrm{~g} / \mathrm{cm}^{3}$ [65]. The particle size distribution is uneven, which means it can form a good structure [66]. The bottom ash mainly contains ceramics, glass fragments, metal products, and some unburned or 


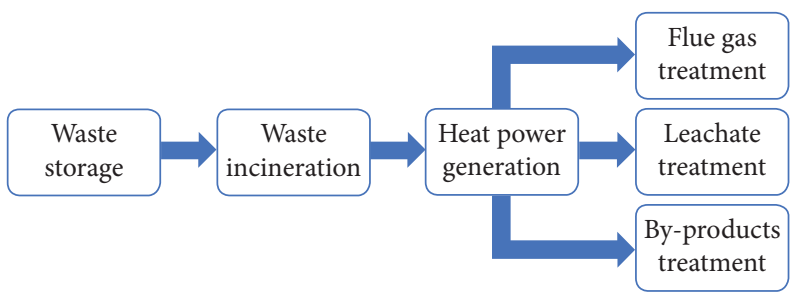

FIgURE 1: MSWI process.

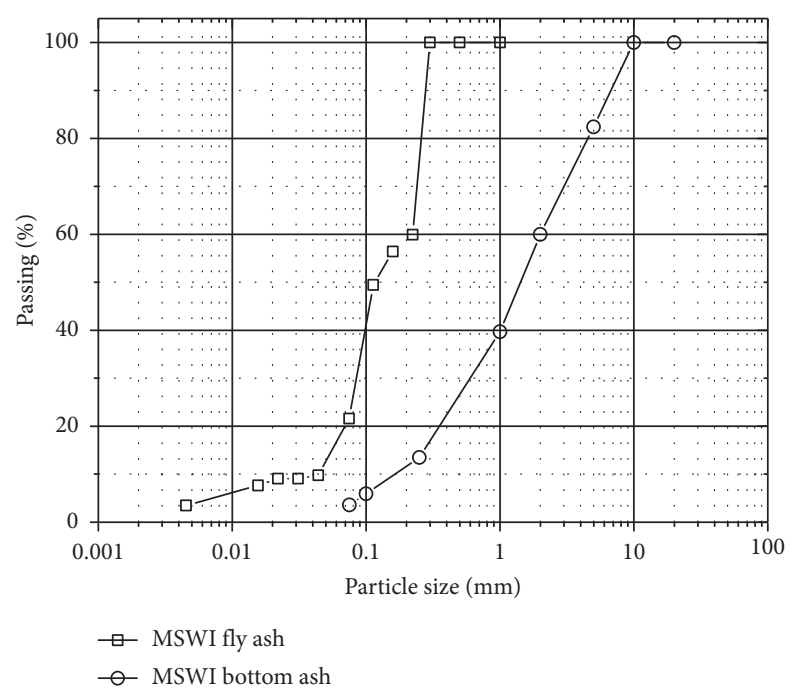

Figure 2: Particle size distribution of MSWI fly ash and bottom ash.

TABLe 1: Compounds of MSWI fly ash and bottom ash.

\begin{tabular}{|c|c|c|c|c|c|c|c|c|}
\hline \multirow{2}{*}{ Compound } & \multicolumn{4}{|c|}{ Fly ash (wt.\%) } & \multicolumn{4}{|c|}{ Bottom ash (wt.\%) } \\
\hline & China & Portugal & Japan & France & China & Portugal & France & Italy \\
\hline $\mathrm{SiO}_{2}$ & 19.81 & 3.25 & 12.01 & 27.23 & 55.2 & 43.75 & 49.3 & 37.78 \\
\hline $\mathrm{CaO}$ & 23.63 & 38.7 & 13.86 & 16.42 & 15.9 & 22.77 & 16.3 & 23.29 \\
\hline $\mathrm{Al}_{2} \mathrm{O}_{3}$ & 6.79 & 2.31 & 8.1 & 11.72 & 9.6 & 6.81 & 7.5 & 11.88 \\
\hline $\mathrm{Na}_{2} \mathrm{O}$ & 6.68 & 11.57 & 17.19 & 5.86 & 5.1 & 7 & 6 & 3.7 \\
\hline $\mathrm{K}_{2} \mathrm{O}$ & 6.23 & 8.35 & 7.41 & 5.8 & 1.7 & 3.12 & 1.1 & 1.63 \\
\hline $\mathrm{Fe}_{2} \mathrm{O}_{3}$ & 4 & 0.39 & 1.21 & 1.8 & 5.7 & 2.03 & 7.6 & 8.01 \\
\hline $\mathrm{MgO}$ & 3.78 & 1.67 & 2.62 & 2.52 & 2.6 & 5.11 & 2.6 & 3.87 \\
\hline $\mathrm{ZnO}$ & 2.79 & 0.54 & 1.19 & 1.37 & & 0.65 & & 0.58 \\
\hline $\mathrm{Cl}$ & 10.16 & 27.06 & 14.95 & 7.2 & & 2.42 & 0.3 & \\
\hline $\mathrm{SO}_{3}$ & 8.74 & 4.59 & 5.54 & 3 & 0.9 & 6.34 & 0.4 & \\
\hline Others & 7.39 & 1.57 & 15.92 & 17.08 & 3.3 & 0 & 8.9 & 9.26 \\
\hline
\end{tabular}

nonburned substances. Since bottom ash needs to be cooled by water washing, the fresh bottom ash has high water content and a slight pungent odor. The color of the freshly burned bottom ash is gray-black, and it becomes gray-white after drying. The large-diameter bottom ash is mainly made of ceramic pieces, bricks, and metal products, and the smalldiameter part is mainly made of glass and ash. Because the bottom ash contains a large amount of metal elements, its $\mathrm{pH}$ value exceeds 7 and the aqueous solution is alkaline.

The main composition of bottom ash is mainly determined by MSW. The loss on ignition is $1 \%-4 \%$. It is mainly composed of $\mathrm{Si}, \mathrm{Ca}, \mathrm{Al}, \mathrm{Fe}$, and other elements. Compared with fly ash, the ratio of $\mathrm{SiO}_{2}$ and $\mathrm{CaO}$ in bottom ash is more than $60 \%$, which is very helpful for the strength of bottom ash [67-69]. The content of heavy metals in bottom ash is less than that in fly ash, which is more environment friendly.

It should be noted that due to the different sources, types, and incineration conditions of MSW, the properties of MSW vary in different regions. However, in the same region, this difference is not obvious. The data in this paper are the average values in the literature. 
3.2. Leaching Characteristics of Heavy Metals. Since MSWI fly ash and bottom ash contain heavy-metal elements, the leaching of heavy metals should be detected to assess the impact on the environment. The heavy metals in them are mainly $\mathrm{Zn}, \mathrm{Cu}, \mathrm{Pb}$, and $\mathrm{Cr}$, but the content of heavy metals in bottom ash is lower than that in fly ash. The heavy metals in them are shown in Table 2 [70-73].

Due to the heavy metals in them, leaching tests need to be carried out to evaluate the environmental influence. The leaching amount of $\mathrm{Zn}, \mathrm{Pb}, \mathrm{Cd}$, and $\mathrm{Cr}$ in fly ash is relatively large, which exceeds the relevant requirements. The leaching concentration is shown in Table 3 [74-77]. Therefore, pretreatment must be carried out before use.

Leaching is related to raw materials, $\mathrm{pH}$ value, liquidsolid ratio, particle size, and other factors [78-81]. Due to the different contents of heavy metals in different raw materials, the leaching results are quite different. Generally, higher content of heavy metals in raw materials means greater leaching amount. The effect of $\mathrm{pH}$ is complex, which is related to the heavy metals. For heavy metals such as $\mathrm{Ba}, \mathrm{Cu}$, and $\mathrm{Ti}$, the leaching concentration in acidic condition is much higher than that in $\mathrm{pH}=7$ [82-84]. However, for $\mathrm{Mn}$ and $\mathrm{Zn}$, the change of $\mathrm{pH}$ has little effect. Higher liquid-solid ratio means lower leaching concentration of heavy metals [85]. When the solid-liquid ratio is low, the solution is easy to be saturated and cannot continue to leach heavy metals. When the solid-liquid ratio increases gradually, the leaching of heavy metals begins to increase until the upper limit of leaching is reached. The particle size determines the specific surface area of the particles [86]. A smaller particle means a larger specific surface area and a larger reaction area [87]. However, because both bottom ash and fly ash have certain adsorption capacity, leaching and adsorption reactions are conducted in the leaching process, both of which are sensitive to specific surface area [88-92]. Therefore, the influence of particle size is complex, which needs to be evaluated according to the type of heavy metals. According to the relevant research, the leaching concentration of $\mathrm{Cd}$ and $\mathrm{Cr}$ increases with the decrease in particle size, while this is the opposite for $\mathrm{Cu}, \mathrm{Ba}$, and $\mathrm{Mn}$ [83, 93-95].

The leaching characteristics of heavy metals in bottom ash are similar to those in fly ash $[96,97]$. Different from fly ash, due to the composition and structure of bottom ash, heavy-metal leaching is much less than fly ash [98]. According to the research, the leaching of bottom ash can basically meet the requirements of various national standards, which means that it can be directly used without pretreatment [99-101]. However, in the case of low $\mathrm{pH}$ value, the leaching of heavy metals may still exceed the requirements. In addition, the long-term leaching characteristics of bottom ash still need to be observed.

\section{Pretreatments of MSWI Fly Ash and Bottom Ash}

The pretreatments of MSWI fly ash and bottom ash are divided into separation, solidification/stabilization, and heat treatments. The comparison of different pretreatments is shown in Table 4.
4.1. Separation. Separation refers to the separation of heavy metals, soluble salts, and other substances by physical, chemical, or biological methods. The commonly used separation methods are washing, leaching, and electro-osmosis. Among them, washing is mainly used to separate soluble salts and surface dust, leaching is mainly used to remove and recover heavy metals, and electro-osmosis is used to remove heavy metals and chlorides.

4.1.1. Washing. Washing is a common pretreatment method to remove soluble salts by water. Washing can effectively remove soluble substances, such as $\mathrm{Na}^{+}, \mathrm{K}^{+}$, and $\mathrm{Cl}^{-}$[102] . In the washing process, with the increase in the liquid-solid ratio, the extraction efficiency of $\mathrm{Pb}$ and $\mathrm{Ca}$ increased. When the liquid-solid ratio was 100, the maximum extraction efficiency was $78 \%$ and $78.25 \%$, respectively. However, the increase in the liquid-solid ratio had no obvious effect on the extraction efficiency of $\mathrm{Cu}, \mathrm{Zn}, \mathrm{Cr}$, and $\mathrm{Cd}$. After washing, the main components are silicates and metal sulfides. However, $\mathrm{Zn}$ and $\mathrm{Cd}$ cannot be effectively removed after washing [102]. After washing, by adjusting the $\mathrm{pH}$ value to 6.5-7.5, $\mathrm{Al}$ is precipitated in the form of metal hydroxide, and other heavy metals can be adsorbed on $\mathrm{Al}(\mathrm{OH})_{3}$ colloid. The remaining resulting sludge can be mixed in cement for solidification [103].

The washing process is easy to operate, its cost is low, and it can effectively remove the dust and soluble substances on the surface, so it is widely used in practice [104-106]. However, the effect on the removal of insoluble salt or slightly soluble salt is not good. After washing, heavy metals still cannot meet the requirements of relevant standards [107-109]. It can be used in combination with other processing methods.

4.1.2. Leaching. In order to extract heavy metals further, other solvent solutions can be used. The leaching agents can be divided into three types: the acid leaching agent, alkaline leaching agent, and biological leaching agent. Heavy metals, such as $\mathrm{Zn}, \mathrm{Pb}, \mathrm{Cu}$, and $\mathrm{Al}$, can be recovered by the leaching process. The effect of leaching depends on heavy metals, leaching agents, $\mathrm{pH}$ value, and liquid-solid ratio. It is also affected by temperature and time. In general, higher heavymetal concentration and liquid-solid ratio can get greater leaching amount. The acid leaching agents include $\mathrm{HCl}$, $\mathrm{H}_{2} \mathrm{SO}_{4}, \mathrm{HNO}_{3}$, and other inorganic acids [82]. Acid leaching has good leaching effect and high extraction efficiency, but it is expensive $[110,111]$. Compared with the acid leaching agent, the alkaline leaching agent has better effect on specific metal elements (such as $\mathrm{Zn}$ and $\mathrm{Pb}$ ) [112]. In addition, the combination of chemical leaching and washing can further improve the removal efficiency of soluble salt in fly ash. Bioleaching is the use of microbial redox reactions in life activities to separate heavy metals. The typical application is hydrometallurgy. Compared with chemical leaching, bioleaching is more environment friendly. The factors affecting the bioleaching of fly ash include pretreatment, concentration of fly ash, and bacteria species [113]. Bioleaching was 
TABLE 2: Heavy metals in MSWI fly ash and bottom ash.

\begin{tabular}{|c|c|c|c|c|c|c|c|}
\hline & \multirow{2}{*}{ Country } & \multicolumn{6}{|c|}{ Heavy metal concentration $(\mathrm{mg} / \mathrm{kg})$} \\
\hline & & $\mathrm{Cr}$ & $\mathrm{Pb}$ & $\mathrm{Cu}$ & $\mathrm{Zn}$ & $\mathrm{Cd}$ & $\mathrm{Ni}$ \\
\hline \multirow{4}{*}{ Fly ash } & China & 180 & 2710 & 990 & 4530 & 90 & 70 \\
\hline & Spain & 790 & 398 & 156 & 15900 & 6 & 90 \\
\hline & Japan & 235 & 3750 & 1800 & 21000 & 225 & \\
\hline & Italy & 109 & 964 & 173 & & 85 & 45 \\
\hline \multirow{4}{*}{ Bottom ash } & China & 577 & 470 & 841 & 9782 & 9.9 & 142 \\
\hline & Japan & 185 & 2462 & 586 & 1694 & 83.4 & 61 \\
\hline & USA & 1421 & 4300 & 3090 & 1360 & 71 & 49 \\
\hline & Spain & 112 & 3334 & 4859 & 3518 & 0.5 & 127 \\
\hline
\end{tabular}

TABLE 3: Leaching concentration of MSWI fly ash and bottom ash.

\begin{tabular}{lccc}
\hline Heavy metal & Fly ash $(\mathrm{mg} / \mathrm{L})$ & Bottom ash $(\mathrm{mg} / \mathrm{L})$ & Limit value $(\mathrm{mg} / \mathrm{L})$ \\
\hline $\mathrm{Cd}$ & 2.35 & $<0.01$ & 0.03 \\
$\mathrm{Cu}$ & 0.21 & 3.30 & 0.5 \\
$\mathrm{Cr}$ & 0.42 & 0.18 & 0.5 \\
$\mathrm{Ni}$ & 0.23 & 0.15 & 0.75 \\
$\mathrm{~Pb}$ & 0.14 & 0.16 & 1.3 \\
$\mathrm{Zn}$ & 36.99 & 0.73 & 2.8 \\
\hline
\end{tabular}

Table 4: Pretreatment methods of MSWI fly ash and bottom ash.

\begin{tabular}{|c|c|c|c|c|c|c|c|}
\hline & \multicolumn{3}{|c|}{ Separation } & \multicolumn{3}{|c|}{ Solidification/stabilization } & \multirow{2}{*}{$\begin{array}{c}\text { Heat } \\
\text { treatment }\end{array}$} \\
\hline & Washing & Leaching & Electrodialysis & $\begin{array}{c}\text { Cement solidification } \\
\text { technology }\end{array}$ & $\begin{array}{l}\text { Melt curing } \\
\text { technology }\end{array}$ & $\begin{array}{c}\text { Chemical } \\
\text { stabilization }\end{array}$ & \\
\hline $\begin{array}{l}\text { Removal effect of } \\
\text { heavy metals }\end{array}$ & $\mathrm{Bad}$ & Excellent & Good & Excellent & Excellent & Excellent & Excellent \\
\hline Secondary pollution & Yes & Yes & Yes & No & Yes & No & Yes \\
\hline Cost & Low & High & High & Medium & Medium & Medium & Medium \\
\hline Technical difficulty & Low & Medium & High & Low & Medium & Medium & Low \\
\hline Strength increase & Low & Low & Low & High & Medium & Mid & Medium \\
\hline
\end{tabular}

originally used to extract metals from minerals, and the application of bioleaching in fly ash is still relatively rare.

Leaching can effectively remove heavy metals, and the operation is relatively simple. However, chemical leaching needs to consume a lot of chemical reagents, and because of the low content of heavy metals in fly ash, the economic benefit is not good. Compared with chemical leaching, bioleaching is more environment friendly. However, it takes a lot of time to culture bacteria, and bioleaching technology is not mature enough. Further research is needed for bioleaching.

4.1.3. Electrodialysis. The principle of electrodialysis is the reduction/oxidation reaction at the interface between the electrode and electrolyte [114]. In the process of electrodialysis, the reduction reaction of the cathode produces hydrogen and metal and the oxidation reaction of the anode produces oxygen. The influence factors include current density, temperature, mixing conditions, and $\mathrm{pH}$ value. In the process of metal precipitation, the inert metal is first precipitated, and then, the active metal is precipitated. The toxicity of inert metals is generally greater than that of active metals, so this method has a good removal of toxicity of fly ash [115]. In addition, acidic agent, alkaline agent, or complexing agent can be added to the solution to increase the conductivity of the solution and improve the efficiency of metal leakage. The selective ion exchange membrane can also increase the metal precipitation efficiency [116].

Electrodialysis can effectively remove dissolved heavy metals and chlorides. However, electrodialysis is not effective for the removal of insoluble or slightly soluble heavy metals [117]. This method needs a lot of electric energy, and the economic benefit is not good.

4.2. Solidification/Stabilization Technology. Solidification/ stabilization technology originated from the treatment of radioactive waste in the 1950s, and it developed rapidly in the 1980s. The solidification/stabilization technology mainly includes cement solidification, chemical agent stabilization, melting solidification, and chemical stabilization. 
Solidification refers to the process in which the hazardous substances in the waste become immobile and form a compact solid after mixing the curing agent with the waste, and stabilization refers to the process in which the harmful substances in the waste are transformed into toxic substances by adding chemicals.

4.2.1. Cement Solidification Technology. Cement solidification technology refers to mixing MSWI ash into the cement and water for the hydration reaction to occur and form a calcium silicate hydrate product with low heavy-metal leaching toxicity and good long-term stability [118-120]. In the hydration process of cement, heavy metals can react with cement by adsorption, sedimentation, ion exchange, passivation, and other ways [36]. Cement curing after washing has no effect on the setting time of cement, and its strength is improved compared with ordinary cement [121, 122]. However, the addition of excessive fly ash may lead to longer initial and final setting times, and the flexural and compressive strength of cement will also decrease [112].

Cement solidification technology is the most commonly used solidification technology for hazardous waste treatment in the world, with the advantages of wide sources of materials, simple equipment and technology, low treatment cost, and high strength of solidified products [123]. However, this method requires a lot of cement, and the volume after treatment has an obvious increase. If the solidified fly ash is put in the landfill site, it will occupy more spaces and increase the cost [124]. Thus, it is reasonable to be used as construction materials after solidification.

4.2.2. Melt Curing Technology. Melting and solidification is a process in which the fly ash is heated to $1400^{\circ} \mathrm{C}$ to make it melt and then cooled into slag by a certain program. The volume reduction of fly ash after melt treatment can reach $1 / 3-1 / 2$, and most of dioxins in fly ash are decomposed [125]. The final product of melt is a completely amorphous and homogeneous vitreous body [34]. Adding $\mathrm{SiO}_{2}, \mathrm{MgO}$, $\mathrm{CaF}_{2}$, borax, coke, and other auxiliary materials to the fly ash can reduce the melting temperature and reduce the volatilization. The slag can also be made into building materials or used as raw materials for glass, ceramics, and other industries to realize the resource utilization of ash [126]. With the increase of heat treatment temperature, the volatilization of pollutants also increases. This treatment also reduced weight loss and enhanced the solidification of pollutants.

Although the melt solidification technology can greatly reduce the volume of fly ash and the leaching toxicity of heavy metals and realize the resource utilization while reducing and harmless, the melting solidification technology has large energy consumption and high cost. Generally, it is only considered to use when processing high-dose radioactive waste or highly toxic waste, so it is limited to a large extent. At the same time, due to the volatilization of $\mathrm{Pb}, \mathrm{Cd}$, and other low-boiling point heavy-metal salts in fly ash under high temperature conditions, the content of heavy metals in flue gas is very high and the flue gas needs to be treated strictly, which increases the cost.

4.2.3. Chemical Stabilization. Medicament stabilization is a process of making toxic and harmful substances into lowtoxicity substances through chemical reactions [127]. Chemical agents can be divided into inorganic curing agents and organic curing agents. Inorganic curing agents include $\mathrm{NaOH}, \mathrm{Na}_{2} \mathrm{~S}$, phosphate, and ferrous salt, while organic curing agents include EDTA and its sodium salt, polyamines, and their derivatives [128]. It is found that the leaching rate of heavy metals in fly ash after phosphate treatment is very small, and the fly ash treated by ferrite has good leaching resistance [81]. However, after using an inorganic curing agent to solidify heavy metals in MSWI fly ash, when the environmental $\mathrm{pH}$ value changes, it may lead to the secondary leaching of heavy metals, which makes the leaching toxicity in the treated residues exceed the standard. It is difficult to meet the long-term safety requirements of hazardous waste treatment [129]. The fly ash treated with a heavy-metal chelating agent has strong acid and alkaline impact resistance power.

Compared with other curing and stabilization methods, the chemical reagent stabilization method has the advantages of being harmless, less or no compatibilization, and lower treatment cost and has recently become a hot spot in international environmental research. However, due to the complexity of fly ash components and heavy metal forms and the relatively high cost of chemical stabilizers, it is difficult to find a widely applicable chemical stabilizer. Moreover, the stabilized compounds treated with fly ash lack of cementitious substances, and its strength cannot be improved.

4.3. Heat Treatment. Heat treatment can remove heavy metals or form stable oxides by evaporation at high temperature. This method has a good effect on $\mathrm{Zn}, \mathrm{Pb}, \mathrm{Cr}$, and Ca. Dioxins can also decompose at high temperatures. Heat treatment is usually carried out at $1300-1400^{\circ} \mathrm{C}$ [130]. The waste gas of heat treatment contains heavy metal pollutants and needs to be treated separately. By using additives, controlling temperature, or other pretreatment methods, the concentration of pollutants in the gas can be reduced and the performance of heat treatment can be improved [131]. Heat treatment works in two ways: thermal separation and thermal curing. Thermal separation refers to the separation of heavy metals by evaporation at high temperature. Thermal solidification refers to the immobilization of heavy metals in the products by the formation of stable products. Compared with that before heat treatment, the porosity of the products after heat treatment is lower, and the strength is higher [132].

Due to the different evaporation temperatures of various metals, it is theoretically possible to remove different heavy metals by adjusting the temperature. The strength of products after heat treatment is higher than that before heat treatment. However, this process requires a lot of energy and produces pollution gas [133]. The application of heat treatment in fly ash needs further research. 


\section{Utilization of MSWI Fly Ash and Bottom Ash}

5.1. Utilization of MSWI Fly Ash. MSWI fly ash is rich in many harmful heavy metals and salts, such as $\mathrm{Cd}, \mathrm{Pb}, \mathrm{Zn}, \mathrm{Cr}$, and so on. Therefore, considering the heavy metals and its characteristics of easy enrichment and nondegradation, fly ash is considered as a hazardous waste. Fly ash must be pretreated before transportation and safe landfill disposal [134]. The comparison of different utilization methods is shown in Table 5.

5.1.1. Cement Raw Meal. MSWI fly ash contains $\mathrm{CaO}, \mathrm{SiO}_{2}$, $\mathrm{Al}_{2} \mathrm{O}_{3}$, and some other silicate and aluminosilicate, which means that the composition of MSWI fly ash is similar to that of cement. Therefore, MSWI fly ash can be used as cement raw meal [135]. CaO in ordinary cement needs to be generated by calcining limestone at high temperature, so the energy consumption is relatively high [136]. Compared with Portland cement, cement with part of MSWI fly ash has the advantages of low energy consumption and short setting time. What's more, it can also reduce the emission of $\mathrm{CO}_{2}$, which is known as greenhouse gas [29]. With the increase of fly ash content, the burnability of cement raw meal is obviously improved, but the strength of clinker will reduce. When fly ash is used as raw meal for sulphate aluminate cement, the content of fly ash in raw meal should not exceed $30 \%$ [137]. However, the quality of cement will be affected by the high content of chloride in MSWI fly ash, and the accumulation of heavy metals in cement may lead to environmental problems. If the content of heavy metal can be effectively removed by fly ash pretreatment and the dosage of fly ash is strictly limited, the product quality and the environmental pollution can be controlled [138].

5.1.2. Cement Concrete Aggregate. Due to the small particle size and good strength of it, fly ash can be used as cement concrete aggregate. Lightweight aggregate can be prepared by using the mixture of cement, fly ash, and bottom ash, but the fly ash content should be less than $10 \%$ to meet the performance requirements. The strength of cement concrete is not as good as that without fly ash $[139,140]$. In addition, water washing pretreatment can improve the quality of cement concrete. Although many studies have shown that the leaching toxicity of heavy metals is not high, the environmental pollution risk of long-term heavy metal leaching behavior is possible [141, 142].

5.1.3. Ceramic. Because the fly ash contains $\mathrm{SiO}_{2}, \mathrm{Al}_{2} \mathrm{O}_{3}$, and $\mathrm{CaO}$, it can replace part of clay to produce ceramics without pretreatment. Pollutants such as dioxins and heavy metals can be solidified in amorphous glass and removed by hightemperature verification [143]. By mixing fly ash, broken glass, feldspar, and other materials, ceramic products have good chemical stability and strength, which is equivalent to the properties of industrial alkali lime glass [144]. Since fly ash contains some glass phase, silicate, aluminum silicate, and quartz, it can be used as a mixture of ceramic tiles [145].
By sintering at temperatures above $900^{\circ} \mathrm{C}$, heavy metals can be consolidated, and the leaching toxicity can be greatly reduced. According to relevant research, the leaching amount of $\mathrm{Cd}, \mathrm{Zn}$, and $\mathrm{Pb}$ is reduced to $0.53 \%, 0.59 \%$, and $0.08 \%$, respectively [146]. Therefore, using fly ash as tiles is an effective method to stabilize heavy metals including $\mathrm{Cd}$, $\mathrm{Hg}, \mathrm{Pb}$, and $\mathrm{Zn}$.

5.1.4. Fertilizer or Soil Improver. Because of the potassium element in fly ash, it can replace part of fertilizer application. In addition, fly ash can be added to the soil instead of lime to adjust the $\mathrm{pH}$ value of the soil [147-149]. Heavy metals in fly ash are toxic to animals and plants, and high salinity will lead to plant salt imbalance. Therefore, independent of whether fly ash is used as a plant fertilizer or soil improver, the amount of fly ash should be strictly controlled.

5.1.5. Adsorbent. Adsorption technology is widely used to remove pollutants from wastewater [150-152]. The development and research of adsorbents with better performance and lower cost has become one of the current hot spots. MSWI bottom ash has been used to remove dyes, heavy metals, and other pollutants from wastewater. MSWI fly ash and bottom ash can be used as adsorbents with good performance for pollutants in sewage and agricultural runoff [153]. However, the problem of using fly ash as adsorbent to treat wastewater is the leaching risk of heavy metals because the toxicity in leaching solution is very high, and this limits the use value of fly ash as an adsorbent [154].

5.1.6. Highway Engineering Material. In the aspect of road materials, most studies focus on the incineration bottom ash or the mixture of bottom ash and fly ash, and the research on using fly ash alone for road construction is less. In order to prevent heavy metals and other pollutants in fly ash from seeping into soil along with rainwater, fly ash is mainly used in the lower structure layer of roads. The application of fly ash in highway engineering materials will be discussed in the following section.

5.2. Utilization of MSWI Bottom Ash. The content of heavy metals in bottom ash is less than that in fly ash, which has little harm to the environment and has great potential for resource utilization [155]. In developed countries, the bottom ash is often widely used for soil improvement, asphalt concrete aggregate, and road materials, and the utilization rate is as high as $70 \%-90 \%$. In China, bottom ash is mainly used to make hollow brick and cement concrete aggregate.

5.2.1. Cement Concrete Aggregate. MSWI bottom ash has been widely used as cement concrete aggregate [156-158]. Because of the low heavy-metal content and high strength, the bottom ash is an ideal aggregate substitute. Through research, it is found that the cement concrete product with bottom ash instead of part of aggregate has good performance. However, some chemical components in the bottom 
TABLE 5: Utilization of MSWI fly ash and bottom ash.

\begin{tabular}{|c|c|c|c|c|}
\hline & Products & Economic benefits & Leaching toxicity & Pretreatment requirement \\
\hline \multirow{6}{*}{ Fly ash } & Cement raw meal & High & Low & No \\
\hline & Cement concrete aggregate & High & Low & No \\
\hline & Ceramic & Middle & Low & No \\
\hline & Adsorbent & Middle & High & Yes \\
\hline & Landfill cover material & Middle & High & Yes \\
\hline & Highway engineering material & & See Table 7 & \\
\hline \multirow{4}{*}{ Bottom ash } & Cement concrete aggregate & High & Low & No \\
\hline & Ceramic or brick & Middle & Low & No \\
\hline & Landfill cover material & Low & Low & No \\
\hline & Highway engineering material & & See Table 7 & \\
\hline
\end{tabular}

ash may affect the performance of cement concrete, such as chlorides and sulfates. Chlorides and sulfates may cause corrosion of steel bars and damage of cement concrete. The metal cations can delay the setting time of cement concrete [159]. Al in the bottom ash will also generate hydrogen due to the alkaline environment formed by cement hydration, which will lead to the existence of bubbles in cement concrete and reduce the product quality [160]. Therefore, pretreatment can be carried out before the aggregate is made to reduce the heavy metal content and improve the product performance.

5.2.2. Ceramic or Brick. Because of its high strength, bottom ash can be used as ceramic or brick raw material [161-163]. Using bottom ash as raw material does not reduce the strength of the product [164]. However, the product performance is controlled by temperature, sintering method, bottom ash gradation, and other influencing factors, and the product performance is not stable due to the complex composition of bottom ash [165]. Pretreatment can be carried out before sintering to improve product performance.

5.2.3. Landfill Cover Material. Because of the low content of heavy metals in the bottom ash, it can be used as the covering material of the landfill site $[100,166,167]$. This is one of the main ways to use bottom ash in the United States. But, the landfill itself occupies a lot of land resources, and the economic benefit is not good [168]. In addition, with the increasing amount of bottom ash and fly ash, the landfill exceeds its bearing capacity.

5.2.4. Highway Engineering Materials. Compared with fly ash, MSWI bottom ash has good strength and low heavy metal content, so it is widely used in highway engineering, including pavement and subgrade materials. Its application in highway engineering will be introduced in detail below.

Developing countries need to further improve and develop infrastructure, and longer mileage of railway and highway transportation facilities will be built in the coming years. These will undoubtedly consume a huge amount of building materials including stone and sand. However, the environment has been seriously damaged due to the excessive exploitation of sand and gravel. Many local governments have formulated relevant policies to limit the further exploitation of natural sand and stone. In this context, MSWI fly ash and bottom ash are encouraged as highway materials.

\section{Utilization of MSWI Fly Ash and Bottom Ash in Highway Engineering}

6.1. Application in Asphalt Pavement Material. In the aspect of highway engineering utilization, more research is focused on MSWI bottom ash or mixture of bottom ash and fly ash, while less research is focused on using fly ash alone. As the hazardous substances such as heavy metals in MSWI fly ash are easy to leach, it is mainly used in the lower layer structure of the highway to avoid direct contact with rainwater [169]. As heavy metals in fly ash can be solidified by asphalt, it can be used in asphalt mixture [170]. However, pretreatment must be carried out before this to reduce the impact on the environment and improve asphalt mixture quality.

The leaching concentration of heavy metals must be considered when MSWI fly ash is used in asphalt pavement. The performance of Marshall stability, water sensitivity, resilient modulus, fatigue life, and rutting of asphalt mixture with fly ash in the range of $8 \%-16 \%$ designed by Marshall and superior performance asphalt pavements (SUPERPAVE) design procedures is better than that of ordinary Marshall mixture [135, 171]. Compared with cement solidification, the leaching amount is better than that of cement and can meet the requirements of the EPA standard [172]. The leaching concentration of fly ash after asphalt solidification is shown in Table 6 . However, the long-term road performance and leaching of asphalt mixture still lack of relevant research.

Compared with fly ash, bottom ash has higher strength and lower heavy metal leaching, so it has been widely used in asphalt pavement. The bottom ash can replace part of the aggregate in the asphalt mixture, indicating that the asphalt mixture has a good road performance [173-175]. Compared with coarse aggregate, bottom ash is more likely to replace fine aggregate. When the bottom ash is used as aggregate, the elastic modulus and tensile strength of asphalt mixture can be improved $[176,177]$. When MSWI bottom ash is added as filling material, the elastic modulus, tensile strength, and fracture performance of asphalt mixture can be improved reliably $[42,178-181]$. When $20 \%$ of bottom ash is added, the 
TABLE 6: Leaching concentration of fly ash after asphalt solidification.

\begin{tabular}{lcccc}
\hline Heavy metal & Content $(\mathrm{mg} / \mathrm{kg})$ & Without solidification & \multicolumn{2}{c}{ Leaching concentration $(\mathrm{mg} / \mathrm{L})$} \\
& & 45 & 4.79 & 6.21 \\
$\mathrm{Cu}$ & 670 & 23 & 0.97 & 1.08 \\
$\mathrm{Cd}$ & 276 & 331 & 0.63 & 1.05 \\
$\mathrm{~Pb}$ & 4744 & 622 & 119.12 & 67.94 \\
$\mathrm{Zn}$ & 10259 & 25 & 3.61 & 3.46 \\
$\mathrm{Cr}$ & 450 & 6 & 0.95 & 1.2 \\
$\mathrm{Ni}$ & 68 & & \\
\hline
\end{tabular}

performance of hot mix asphalt is the best, which has a good compression performance and antirutting performance. The mixing of bottom ash can also improve the antiwear ability of the surface course and improve the friction force $[182,183]$. There have been many practices in the use of MSWI bottom ash in the surface layer, but there is still a lack of relevant research on the field construction and long-term performance testing $[184,185]$. In addition, the unburned heavy metals in bottom ash need to be removed by sieving and magnetic separation to improve the quality of products.

6.2. Application in Base and Subbase Material. Because the base is between the surface layer and the subgrade, it will not directly contact with water and soil, so it reduces the risk of heavy metal pollution and is regarded as an ideal recycling method of fly ash and bottom ash [43, 186, 187]. Considering the environmental safety and structural characteristics, fly ash and bottom ash must be pretreated before they are used as base materials [188]. Fly ash and bottom ash are widely used as base or subbase materials, and a large number of studies have been carried out in developed countries such as Holland, Spain, the United States, and France [42].

Fly ash and bottom ash need to be washed, cemented, or melted curing before being used as base materials. The strength requirement of highway base is very high, which mainly adopts cement-stabilized base, asphalt-stabilized base, or granular base [189]. Due to the poor solidification effect of granular base for heavy metals, bottom ash and fly ash are more commonly used in cement-stabilized base and asphalt base.

The properties of cement base are similar to those of cement concrete [74]. Because the base needs to bear a lot of load, the base must have enough stiffness and strength. The application of fly ash or bottom ash in cement stabilized base course can not only replace part of aggregate but also has little influence on the strength of products. However, $\mathrm{Cl}$ and $\mathrm{Al}$ will affect the quality of the base course, leading to cracks more easily. Due to the higher leaching risk of heavy metals in fly ash, chemical pretreatment is needed, which will increase the cost and put the fly ash at a disadvantage in practice. Therefore, it is a better choice to use bottom ash in base or subbase [190].

The asphalt base course is similar to asphalt pavement, so we will not repeat it here. It should be pointed out that asphalt is not suitable for heavy traffic because its modulus is lower than that of cement-stabilized base. Asphalt base is also more expensive, so its use in developing countries is less.
6.3. Application in Subgrade Material. The cost of subgrade material is relatively low, and the cost must be considered when selecting the appropriate subgrade replacement material. Because the heavy metal in fly ash is easy to leach, it must be pretreated before it is used as subgrade material. After solidification of fly ash cement, its strength can meet the requirements of subgrade, and the amount of heavy metal leaching is less [191]. In addition, fly ash can be directly used as subgrade material to waterproof subgrade. Once the leakage occurs, heavy metals will directly enter the soil and groundwater, thus polluting the surrounding environment [188, 192].

The mechanical properties and leaching characteristics of bottom ash are better than those of fly ash, and it has better applicability in road construction [193]. The shear strength, elastic modulus, and bearing ratio of bottom ash are close to those of sand. When the bottom ash is mixed with sand or soil, the strength of the mixture can also be improved [182, 191, 194]. Bottom ash has been widely used as a subgrade filler, and the strength, stability, and durability are good [186]. If it is washed before it is used as subgrade filling material, the chloride and other soluble substances can be reduced, so as to reduce the impact on the surrounding environment [195]. Considering that the price of bottom ash is relatively cheap, the bottom ash is an ideal subgrade material.

6.4. Comparison of Economic and Environmental Benefits of Different Layers. Generally, the structure which is closer to the surface needs to bear the greater load and has to meet higher requirements for the strength and durability. Therefore, road surface materials are often more expensive than base and roadbed materials. Under the premise of meeting relevant requirements, the closer application of fly ash and bottom ash will get more economic benefits if they are used in the top layers. In addition, pretreatment is also a very important factor affecting economic benefits. If the pretreatment means are too complicated or too expensive, it will greatly increase the cost of the project. Compared with fly ash, the bottom ash has very little leaching of heavy metals, and it can be washed or left untreated. Also, the strength of bottom ash is higher than that of fly ash, so it can replace aggregate more. The comparison of economic and environmental benefits is shown in Table 7 .

For the environment, the surface layer and the base layer are the easiest to leach because they are more easily exposed to water. Therefore, fly ash and bottom ash are used in places 
TABLE 7: Comparison of economic and environmental benefits.

\begin{tabular}{|c|c|c|c|c|c|}
\hline & Layers & Economic benefits & Environmental benefits & Pretreatment requirement & Application extent \\
\hline \multirow{3}{*}{ Fly ash } & Asphalt surface course & High & High & No & Middle \\
\hline & Base or subbase & Middle & Middle & Yes & Narrow \\
\hline & Subgrade & Low & Low & Yes & Narrow \\
\hline \multirow{3}{*}{ Bottom ash } & Asphalt surface course & High & High & No & Wide \\
\hline & Base or subbase & High & High & No & Wide \\
\hline & Subgrade & Middle & High & No & Wide \\
\hline
\end{tabular}

that are not in direct contact with water and soil to prevent polluting the environment. Fly ash is often not used in the top layer or subgrade. During the pretreatment process, secondary pollution may also be caused. Suitable materials need to consider both economic and ecological benefits.

\section{Recommendations and Outlook}

Due to its good mechanical properties and low heavy-metal leaching, MSWI bottom ash is widely used in highway engineering materials. MSWI bottom ash has been widely studied and applied in subgrade filling and cement-stabilized macadam aggregate. However, considering its side effect on the quality of asphalt mixture, it is seldom applied in asphalt pavement.

Considering the cost of natural aggregate, MSWI bottom ash as aggregate has a wide prospect in cement-stabilized macadam, especially in developing countries. This is conducive to reduce the cost of highway and promote the development of MSWI to alleviate the ecological problems caused by MSW.

However, due to concerns about heavy-metal leaching, MSWI fly ash is rarely applied in highway engineering. Considering that most of the road surface is impermeable, the application of MSWI fly ash in cement-stabilized macadam has certain potential. In addition, aquifuges can be set to prevent the leaching of heavy metals. Cement is beneficial to play a role in solidification of fly ash to reduce its environmental pollution. However, due to the particle size of fly ash, it can only be used as fine aggregate or mineral powder. The large-scale utilization of fly ash depends on the support of government policies.

\section{Conclusions}

The main conclusions are as follows:

(1) MSWI fly ash and bottom ash are huge in quantity and have certain toxicity. Therefore, it is necessary to find suitable utilization methods to reduce land occupation and environmental pollution.

(2) The main components of MSWI fly ash and bottom ash are $\mathrm{SiO}_{2}, \mathrm{CaO}$, and $\mathrm{Al}_{2} \mathrm{O}_{3}$. However, compared with fly ash, bottom ash has higher $\mathrm{SiO}_{2}$ and $\mathrm{CaO}$ content and lower heavy-metal content; thus, it has higher strength and less heavy-metal leaching.

(3) The main pretreatment methods are separation, solidification/stabilization, and heat treatment. Among them, the separation needs chemical reagents, but heavy metals can be extracted. Solidification/stabilization can reduce the leaching of heavy metals and improve the strength of MSWI fly ash and bottom ash. Although heat treatment has a good effect on reducing the heavy metal leaching, it needs energy consumption and waste gas treatment.

(4) MSWI fly ash is mainly used in cement concrete aggregate, ceramic, adsorbent, fertilizer, and highway engineering materials. MSWI bottom ash is mainly used in cement concrete aggregate, ceramic, landfill covering material, and highway engineering material. Among them, using fly ash and bottom ash as cement concrete aggregate has a good economic benefit, and using as ceramic raw material has a good effect on limiting heavy-metal leaching.

(5) Considering its low strength and serious leaching toxicity, MSWI fly ash is seldom used in highway engineering, especially in the top layer and subgrade. MSWI bottom ash has high strength and less heavymetal leaching; thus, it can be used in all surface layers and has good economic and environmental benefits.

\section{Data Availability}

The data that support the findings of this study are available from the corresponding author, YC Huang, upon reasonable request.

\section{Conflicts of Interest}

The authors declare that they have no conflicts of interest.

\section{Acknowledgments}

The research presented here was supported by the National Nature Science Foundation of China (52078317), Natural Science Foundation of Jiangsu Province (BK20170339), project from Jiangsu Provincial Department of Housing and Urban-Rural Development (2020ZD05), and Bureau of Housing and Urban-Rural Development of Suzhou (201914, 2020-15).

\section{References}

[1] J. B. Richardson, "Urban forests near municipal solid waste incinerators do not show elevated trace metal or rare earth element concentrations across three cities in the northeast USA," Environmental Science and Pollution Research, vol. 27, no. 17, pp. 21790-21803, 2020. 
[2] M. S. Korai, M. Ali, C. Lei, R. B. Mahar, and D. Yue, "Comparison of MSW management practices in Pakistan and China," Journal of Material Cycles and Waste Management, vol. 22, no. 2, pp. 443-453, 2020.

[3] I. Okuda and V. E. Thomson, "Regionalization of municipal solid waste management in Japan: balancing the proximity principle with economic efficiency," Environmental Management, vol. 40, no. 1, pp. 12-19, 2007.

[4] S. Pattnaik and M. V. Reddy, "Assessment of municipal solid waste management in puducherry (pondicherry), India," Resources, Conservation and Recycling, vol. 54, no. 8, pp. 512-520, 2010.

[5] D. A. Colvero, J. Ramalho, A. P. D. Gomes, M. A. A. d. Matos, and L. A. D. C. Tarelho, "Economic analysis of a shared municipal solid waste management facility in a metropolitan region," Waste Management, vol. 102, pp. 823-837, 2020.

[6] S. Xiao, H. Dong, Y. Geng, M.-J. Francisco, H. Pan, and F. $\mathrm{Wu}$, "An overview of the municipal solid waste management modes and innovations in Shanghai, China," Environmental Science and Pollution Research, vol. 27, no. 24, pp. 29943-29953, 2020.

[7] Q. Tang, P. Shi, Y. Zhang et al., "Strength and deformation properties of fiber and cement reinforced heavy metalcontaminated synthetic soils," Advances in Materials Science and Engineering, vol. 2019, 2019.

[8] X. Wang, A. Cao, G. Zhao, C. Zhou, and R. Xu, "Microbial community structure and diversity in a municipal solid waste landfill," Waste Management, vol. 66, pp. 79-87, 2017.

[9] Q. Yang, C. Zuo, X. Liu et al., "Risk response for municipal solid waste crisis using ontology-based reasoning," International Journal of Environmental Research and Public Health, vol. 17, no. 9, 2020.

[10] K. T. Ganson, P. Gould, and R. Holcomb, "Exploring the experiences of male MSW students in the social work learning environment," Journal of Social Work Education, vol. $137,2020$.

[11] Z. Zhang, F. Yang, J.-C. Liu, and S. Wang, "Eco-friendly high strength, high ductility engineered cementitious composites (ECC) with substitution of fly ash by rice husk ash," Cement and Concrete Research, vol. 137, 2020.

[12] A. Iqbal, X. Liu, and G.-H. Chen, "Municipal solid waste: review of best practices in application of life cycle assessment and sustainable management techniques," Science of The Total Environment, vol. 729, 2020.

[13] Z. Zhang, F. Qin, H. Ma, and L. Xu, "Tailoring an impact resistant engineered cementitious composite (ECC) by incorporation of crumb rubber," Construction and Building Materials, vol. 262, 2020.

[14] Q. Tang, F. Gu, Y. Zhang, Y. Zhang, and J. Mo, "Impact of biological clogging on the barrier performance of landfill liners," Journal of Environmental Management, vol. 222, pp. 44-53, 2018.

[15] S. Ma, C. Zhou, G. Yang et al., "Characteristics and environmental impacts of materials stored in municipal solid waste landfills: a case study of the guangdong-Hong KongMacao greater bay area," Huan Jing Ke Xue=Huanjing Kexue, vol. 40, no. 12, pp. 5593-5603, 2019.

[16] O. Adetona, O. B. Ozoh, T. Oluseyi, Q. Uzoegwu, J. Odei, and M. Lucas, "An exploratory evaluation of the potential pulmonary, neurological and other health effects of chronic exposure to emissions from municipal solid waste fires at a large dumpsite in Olusosun, Lagos, Nigeria," Environmental
Science and Pollution Research, vol. 27, no. 24, pp. 3088530892, 2020.

[17] E. Jamroz, J. Bekier, A. Medynska-Juraszek et al., "The contribution of water extractable forms of plant nutrients to evaluate MSW compost maturity: a case study," Scientific Reports, vol. 10, no. 1, 2020.

[18] P. Wijekoon, C. Wickramasinghe, B. C. L. Athapattu et al., "Biomass valorization and phytoremediation as integrated technology for municipal solid waste management for developing economic context," Biomass Conversion and Biorefinery, vol. 10, 2020.

[19] L. Y. Lim, C. T. Lee, C. P. C. Bong, J. S. Lim, and J. J. Klemeš, "Environmental and economic feasibility of an integrated community composting plant and organic farm in Malaysia," Journal of Environmental Management, vol. 244, pp. 431439, 2019.

[20] T.-T. Wang, Z.-Y. Sun, S.-P. Wang, Y.-Q. Tang, and K. Kida, "Succession of total and active microbial community during the composting of anaerobic digested residue," Waste and Biomass Valorization, vol. 11, no. 9, pp. 4677-4689, 2020.

[21] J. Yu, J. Gu, X. Wang et al., "Effects of inoculation with lignocellulose-degrading microorganisms on nitrogen conversion and denitrifying bacterial community during aerobic composting," Bioresource Technology, vol. 313, 2020.

[22] Z. Cheng, Z. Sun, S. Zhu, Z. Lou, N. Zhu, and L. Feng, “The identification and health risk assessment of odor emissions from waste landfilling and composting," Science of The Total Environment, vol. 649, pp. 1038-1044, 2019.

[23] J. García-López, C. Rad, and M. Navarro, "Strategies of management for the whole treatment of leachates generated in a landfill and in a composting plant," Journal of Environmental Science and Health, Part A, vol. 49, no. 13, pp. 1520-1530, 2014.

[24] J.-W. Lu, Y. Xie, B. Xu, Y. Huang, J. Hai, and J. Zhang, "From NIMBY to BIMBY: an evaluation of aesthetic appearance and social sustainability of MSW incineration plants in China," Waste Management, vol. 95, pp. 325-333, 2019.

[25] J. Xu, M. Zhu, and S. Zhao, "Leader-follower optimized approach for carbon-economy equilibrium in the municipal solid waste (MSW) incineration industry," Environmental Science and Pollution Research International, vol. 95, 2020.

[26] A. Beylot and J. Villeneuve, "Environmental impacts of residual municipal solid waste incineration: a comparison of 110 French incinerators using a life cycle approach," Waste Management, vol. 33, no. 12, pp. 2781-2788, 2013.

[27] B. Assamoi and Y. Lawryshyn, "The environmental comparison of landfilling vs. incineration of MSW accounting for waste diversion," Waste Management, vol. 32, no. 5, pp. 1019-1030, 2012.

[28] J.-W. Lu, S. Zhang, J. Hai, and M. Lei, "Status and perspectives of municipal solid waste incineration in China: a comparison with developed regions," Waste Management, vol. 69, pp. 170-186, 2017.

[29] C. Diliberto, E. Meux, S. Diliberto et al., "A zero-waste process for the management of MSWI fly ashes: production of ordinary Portland cement," Environmental Technology, vol. 41, no. 9, pp. 1199-1208, 2020.

[30] Y. Shi, Y. Li, X. Yuan et al., "Environmental and human health risk evaluation of heavy metals in ceramsites from municipal solid waste incineration fly ash," Environmental Geochemistry and Health, vol. 41, 2020.

[31] T. Wang, T. Liu, and C. Sun, "Application of MSWI fly ash on acid soil and its effect on the environment," Waste Management, vol. 28, no. 10, pp. 1977-1982, 2008. 
[32] J. Zhu, Q. Hao, J. Chen, M. Hu, T. Tu, and C. Jiang, "Distribution characteristics and comparison of chemical stabilization ways of heavy metals from MSW incineration fly ashes," Waste Management, vol. 113, pp. 488-496, 2020.

[33] Y. Liu, J. He, L. Chen et al., "Stabilization of heavy metals in MSWI fly ash through sintering with montmorillonitic clay," Research Journal of Chemistry and Environment, vol. 16, pp. 46-55, 2012.

[34] Z. Luo, L. Chen, M. Zhang et al., "Analysis of melting reconstruction treatment and cement solidification on ultrarisk municipal solid waste incinerator fly ash-blast furnace slag mixtures," Environmental Science and Pollution Research, vol. 22, 2020.

[35] W. Chen, F. Wang, Z. Li, and Q. Li, "A comprehensive evaluation of the treatment of lead in MSWI fly ash by the combined cement solidification and phosphate stabilization process," Waste Management, vol. 114, pp. 107-114, 2020.

[36] S. Liang, J. Chen, M. Guo, D. Feng, L. Liu, and T. Qi, "Utilization of pretreated municipal solid waste incineration fly ash for cement-stabilized soil," Waste Management, vol. 105, pp. 425-432, 2020.

[37] H. Ma and Z. Zhang, "Paving an engineered cementitious composite (ECC) overlay on concrete airfield pavement for reflective cracking resistance," Construction and Building Materials, vol. 252, 2020.

[38] Z. Zhang, Q. Zhang, and V. C. Li, "Multiple-scale investigations on self-healing induced mechanical property recovery of ECC," Cement and Concrete Composites, vol. 103, pp. 293-302, 2019.

[39] Z. Zhang, J. Hu, and H. Ma, "Feasibility study of ECC with self-healing capacity applied on the long-span steel bridge deck overlay," International Journal of Pavement Engineering, vol. 20, no. 8, pp. 884-893, 2019.

[40] Z. Haiying, Z. Youcai, and Q. Jingyu, "Study on use of MSWI fly ash in ceramic tile," Journal of Hazardous Materials, vol. 141, no. 1, pp. 106-114, 2007.

[41] R. Cioffi, F. Colangelo, F. Montagnaro, and L. Santoro, "Manufacture of artificial aggregate using MSWI bottom ash," Waste Management, vol. 31, no. 2, pp. 281-288, 2011.

[42] O. Hjelmar, J. Holm, and K. Crillesen, "Utilisation of MSWI bottom ash as sub-base in road construction: first results from a large-scale test site," Journal of Hazardous Materials, vol. 139, no. 3, pp. 471-480, 2007.

[43] M. Izquierdo, X. Querol, A. Josa, E. Vazquez, and A. LópezSoler, "Comparison between laboratory and field leachability of MSWI bottom ash as a road material," Science of the Total Environment, vol. 389, no. 1, pp. 10-19, 2008.

[44] R. Taurino, E. Karamanova, L. Barbieri, S. AtanasovaVladimirova, F. Andreola, and A. Karamanov, "New fired bricks based on municipal solid waste incinerator bottom ash," Waste Management \& Research, vol. 35, no. 10, pp. 1055-1063, 2017.

[45] R. Badreddine and D. François, "Assessment of the PCDD/F fate from MSWI residue used in road construction in France," Chemosphere, vol. 74, no. 3, pp. 363-369, 2009.

[46] A. Damgaard, C. Riber, T. Fruergaard, T. Hulgaard, and T. H. Christensen, "Life-cycle-assessment of the historical development of air pollution control and energy recovery in waste incineration," Waste Management, vol. 30, no. 7, pp. 1244-1250, 2010.

[47] T. Astrup, C. Riber, and A. Pedersen, "Incinerator performance: effects of changes in waste input and furnace operation on air emissions and residues," Waste Management
\& Research: The Journal of the International Solid Wastes and Public Cleansing Association, ISWA, vol. 29, pp. 57-68, 2011.

[48] D. Chen and T. Christensen, "Life-cycle assessment (EASEWASTE) of two municipal solid waste incineration technologies in China," Waste Management \& Research: The Journal of the International Solid Wastes and Public Cleansing Association, ISWA, vol. 28, no. 6, pp. 508-519, 2010.

[49] L. Rigamonti, M. Grosso, and M. Giugliano, "Life cycle assessment for optimising the level of separated collection in integrated MSW management systems," Waste Management, vol. 29, no. 2, pp. 934-944, 2009.

[50] Z. Chu, A. Zhou, Y. Ma et al., "Comparison of municipal solid waste treatment capacity in China: a tournament graph method," Journal of Material Cycles and Waste Management, vol. 29, 2020.

[51] J. L. Domingo, M. Marques, M. Mari et al., "Adverse health effects for populations living near waste incinerators with special attention to hazardous waste incinerators. A review of the scientific literature," Environmental Research, vol. 187, 2020.

[52] A. Maghmoumi, F. Marashi, and E. Houshfar, "Environmental and economic assessment of sustainable municipal solid waste management strategies in Iran," Sustainable Cities and Society, vol. 59, 2020.

[53] M. X. Paes, G. A. de Medeiros, S. D. Mancini et al., "Transition towards eco-efficiency in municipal solid waste management to reduce GHG emissions: the case of Brazil," Journal of Cleaner Production, vol. 263, 2020.

[54] A. Shahnazari, M. Rafiee, A. Rohani et al., "Identification of effective factors to select energy recovery technologies from municipal solid waste using multi -criteria decision making (MCDM): a review of thermochemical technologies," Sustainable Energy Technologies and Assessments, vol. 40, 2020.

[55] D. Tonini, A. Wandl, K. Meister et al., "Quantitative sustainability assessment of household food waste management in the Amsterdam Metropolitan Area," Resources Conservation and Recycling, vol. 160, 2020.

[56] S. Yalcinkaya and O. S. Kirtiloglu, "Application of a geographic information system-based fuzzy analytic hierarchy process model to locate potential municipal solid waste incineration plant sites: a case study of izmir metropolitan municipality," Waste Management \& Research, vol. 160, 2020.

[57] J. R. Pan, C. Huang, J.-J. Kuo, and S.-H. Lin, "Recycling MSWI bottom and fly ash as raw materials for Portland cement," Waste Management, vol. 28, no. 7, pp. 1113-1118, 2008.

[58] D. Zekkos, M. Kabalan, S. M. Syal, M. Hambright, and A. Sahadewa, "Geotechnical characterization of a municipal solid waste incineration ash from a Michigan monofill," Waste Management, vol. 33, no. 6, pp. 1442-1450, 2013.

[59] H. Wu, Y. Zhu, S. Bian, J. H. Ko, S. F. Y. Li, and Q. Xu, "H2S adsorption by municipal solid waste incineration (MSWI) fly ash with heavy metals immobilization," Chemosphere, vol. 195, pp. 40-47, 2018.

[60] Y. Mu, A. Saffarzadeh, and T. Shimaoka, "Influence of ignition process on mineral phase transformation in municipal solid waste incineration (MSWI) fly ash: implications for estimating loss-on-ignition (LOI)," Waste Management, vol. 59, no. 59, pp. 222-228, 2017.

[61] X. Gao, W. Wang, T. Ye, F. Wang, and Y. Lan, "Utilization of washed MSWI fly ash as partial cement substitute with the 
addition of dithiocarbamic chelate," Journal of Environmental Management, vol. 88, no. 2, pp. 293-299, 2008.

[62] N. Cristelo, S. Glendinning, T. Miranda, D. Oliveira, and R. Silva, "Soil stabilisation using alkaline activation of fly ash for self compacting rammed earth construction," Construction and Building Materials, vol. 36, pp. 727-735, 2012.

[63] N. Saikia, G. Cornelis, G. Mertens et al., "Assessment of Pbslag, MSWI bottom ash and boiler and fly ash for using as a fine aggregate in cement mortar," Journal of Hazardous Materials, vol. 154, no. 1-3, pp. 766-777, 2008.

[64] S. Rémond, P. Pimienta, and D. P. Bentz, "Effects of the incorporation of Municipal Solid Waste Incineration fly ash in cement pastes and mortars," Cement and Concrete Research, vol. 32, no. 2, pp. 303-311, 2002.

[65] R. Forteza, M. Far, C. Segú, and V. Cerdá, "Characterization of bottom ash in municipal solid waste incinerators for its use in road base," Waste Management, vol. 24, no. 9, pp. 899-909, 2004.

[66] Q. Alam, A. Lazaro, K. Schollbach, and H. J. H. Brouwers, "Chemical speciation, distribution and leaching behavior of chlorides from municipal solid waste incineration bottom ash," Chemosphere, vol. 241, 2020.

[67] N. Cristelo, L. Segadães, J. Coelho, B. Chaves, N. R. Sousa, and M. de Lurdes Lopes, "Recycling municipal solid waste incineration slag and fly ash as precursors in low-range alkaline cements," Waste Management, vol. 104, pp. 60-73, 2020.

[68] E. Rendek, G. Ducom, and P. Germain, "Carbon dioxide sequestration in municipal solid waste incinerator (MSWI) bottom ash," Journal of Hazardous Materials, vol. 128, no. 1, pp. 73-79, 2006.

[69] L. M. Schabbach, F. Andreola, L. Barbieri et al., "Post-treated incinerator bottom ash as alternative raw material for ceramic manufacturing," Journal of The European Ceramic Society, vol. 32, no. 11, pp. 2843-2852, 2012.

[70] Y. Zhang, Q. Tang, S. Chen et al., "Heavy metal adsorption of a novel membrane material derived from senescent leaves: kinetics, equilibrium and thermodynamic studies," Membrane Water Treatment, vol. 9, no. 2, pp. 95-104, 2018.

[71] Y.-J. Tu, C.-F. You, and C.-K. Chang, "Kinetics and thermodynamics of adsorption for $\mathrm{Cd}$ on green manufactured nano-particles," Journal of Hazardous Materials, vol. 235236, pp. 116-122, 2012.

[72] Q. Tang, P. Shi, Y. Zhang, W. Liu, and L. Chen, "Strength and deformation properties of fiber and cement reinforced heavy metal-contaminated synthetic soils," Advances in Materials Science and Engineering, vol. 2019, pp. 1-9, 2019.

[73] J. M. Chimenos, A. I. Fernández, L. Miralles, M. Segarra, and F. Espiell, "Short-term natural weathering of MSWI bottom ash as a function of particle size," Waste Management, vol. 23, no. 10, pp. 887-895, 2003.

[74] N. H. Le, A. Razakamanantsoa, M.-L. Nguyen, V. T. Phan, P.-L. Dao, and D. H. Nguyen, "Evaluation of physicochemical and hydromechanical properties of MSWI bottom ash for road construction," Waste Management, vol. 80, pp. 168-174, 2018.

[75] J.-w. Ahn, H.-C. Cho, G.-C. Han, G.-S. You, and N.-I. Um, "Characteristic of $\mathrm{Cu}$ and $\mathrm{Pb}$ leaching behavior of municipal solid waste incineration bottom ash," Geosystem Engineering, vol. 9, no. 1, pp. 11-14, 2006.

[76] M. Andac and F. P. Glasser, "The effect of test conditions on the leaching of stabilised MSWI-fly ash in Portland cement," Waste Management, vol. 18, no. 5, pp. 309-319, 1998.
[77] S. Arickx, T. Van Gerven, T. Knaepkens, K. Hindrix, R. Evens, and C. Vandecasteele, "Influence of treatment techniques on $\mathrm{Cu}$ leaching and different organic fractions in MSWI bottom ash leachate," Waste Management, vol. 27, no. 10, pp. 1422-1427, 2007.

[78] J. J. Dijkstra, H. A. van der Sloot, and R. N. J. Comans, "Process identification and model development of contaminant transport in MSWI bottom ash," Waste Management, vol. 22, no. 5, pp. 531-541, 2002.

[79] R. Bie, P. Chen, X. Song, and X. Ji, "Characteristics of municipal solid waste incineration fly ash with cement solidification treatment," Journal of the Energy Institute, vol. 89, no. 4, pp. 704-712, 2016.

[80] V. Intrakamhaeng, K. A. Clavier, J. G. Roessler, and T. G. Townsend, "Limitations of the toxicity characteristic leaching procedure for providing a conservative estimate of landfilled municipal solid waste incineration ash leaching," Journal of the Air \& Waste Management Association, vol. 69, no. 5, pp. 623-632, 2019.

[81] M. Jin, Z. Zheng, Y. Sun, L. Chen, and Z. Jin, "Resistance of metakaolin-MSWI fly ash based geopolymer to acid and alkaline environments," Journal of Non-crystalline Solids, vol. 450, pp. 116-122, 2016.

[82] G. Cornelis, T. Van Gerven, and C. Vandecasteele, "Antimony leaching from uncarbonated and carbonated MSWI bottom ash," Journal of Hazardous Materials, vol. 137, no. 3, pp. 1284-1292, 2006.

[83] K. L. Lin and C. T. Chang, "Leaching characteristics of slag from the melting treatment of municipal solid waste incinerator ash," Journal of Hazardous Materials, vol. 135, no. 1-3, pp. 296-302, 2006.

[84] Q. Tang, P. Shi, Z. Yuan, S. Shi, X. Xu, and T. Katsumi, "Potential of zero-valent iron in remediation of $\mathrm{Cd}(\mathrm{II})$ contaminated soil: from laboratory experiment, mechanism study to field application," Soils and Foundations, vol. 59, no. 6, pp. 2099-2109, 2019.

[85] J. Li, S. Zhang, Q. Wang et al., "Feasibility of using fly ashslag-based binder for mine backfilling and its associated leaching risks," Journal of Hazardous Materials, vol. 400, 2020.

[86] X. Zhao, L.-a. Wang, L. Wang, and W. Zhang, "Distribution of remaining Cd in MSWI fly ash washed with nitric acid," Journal of Material Cycles and Waste Management, vol. 19, no. 4, pp. 1415-1422, 2017.

[87] Q. Alam, A. Lazaro, K. Schollbach et al., "Chemical speciation, distribution and leaching behavior of chlorides from municipal solid waste incineration bottom ash," Chemosphere, vol. 241, 2020.

[88] X. Guo and D. Li, "Solidification/adsorption of heavy metals by FA/FA-MSWI based Al-substituted tobermorite," Journal of Wuhan University of Technology, vol. 34, no. 6, pp. 1345-1349, 2019.

[89] Q. Qiu, X. Jiang, G. Lv et al., “Adsorption of heavy metal ions using zeolite materials of municipal solid waste incineration fly ash modified by microwave-assisted hydrothermal treatment," Powder Technology, vol. 335, pp. 156-163, 2018.

[90] J. Tang, M. Su, L. Wei et al., "Comprehensive evaluation of the effectiveness on metals recovery and decontamination from MSWI fly ash by an integrating hydrometallurgical process in Guangzhou," Science of the Total Environment, vol. 728, 2020.

[91] J. Tang, M. Su, Q. Wu et al., "Highly efficient recovery and clean-up of four heavy metals from MSWI fly ash by 
integrating leaching, selective extraction and adsorption," Journal of Cleaner Production, vol. 234, pp. 139-149, 2019.

[92] J. Yao, Q. Kong, H. Zhu, Z. Zhang, Y. Long, and D. Shen, "Adsorption of ammonia on municipal solid waste incinerator bottom ash under the landfill circumstance," Korean Chemical Engineering Research, vol. 53, no. 4, pp. 503-508, 2015.

[93] P. Ni, Z. Xiong, C. Tian et al., "Influence of carbonation under oxy-fuel combustion flue gas on the leachability of heavy metals in MSWI fly ash," Waste Management, vol. 67, pp. 171-180, 2017.

[94] Q. Qiu, X. Jiang, G. Lv et al., "Evolution of heavy metal speciation in MSWI fly ash after microwave-assisted hydrothermal treatment," Chemistry Letters, vol. 47, no. 8, pp. 960-963, 2018.

[95] H.-S. Shi and L.-L. Kan, "Leaching behavior of heavy metals from municipal solid wastes incineration (MSWI) fly ash used in concrete," Journal of Hazardous Materials, vol. 164, no. 2-3, pp. 750-754, 2009.

[96] L. Ho Nhut, H. Tamura, T. Komiya et al., "Simulating the impact of heavy rain on leaching behavior of municipal solid waste incineration bottom ash (MSWI BA) in semi-aerobic landfill," Waste Management, vol. 113, pp. 280-293, 2020.

[97] H. Kubota, K. Shigeizumi, T. Fujikawa et al., "An accelerated, on-site bottom ash aging and washing treatment and its effect for long-term leaching," Waste and Biomass Valorization, vol. 113, 2020.

[98] Y.-M. Li, X.-Q. Wu, L.-J. Wang et al., "Comparative study on utilization of different types of municipal solid waste incineration bottom ash for clinker sintering," Journal of Material Cycles and Waste Management, vol. 113, 2020.

[99] A. K. Prabhakar, B. Cadiam Mohan, T. S. Tay, S. S Lee, S. L Teo, and C. H Wang, "Incinerated sewage sludge bottom ash- chemical processing, leaching patterns and toxicity testing," Journal of Hazardous Materials, vol. 402, 2020.

[100] J. Yao, Q. Kong, H. Zhu, Y. Long, and D. Shen, "Retention and leaching of nitrite by municipal solid waste incinerator bottom ash under the landfill circumstance," Chemosphere, vol. 119, pp. 267-272, 2015.

[101] Y. Zhao and Y.-T. Zhu, "Metals leaching in permeable asphalt pavement with municipal solid waste ash aggregate," Water, vol. 11, no. 10, 2019.

[102] K.-Y. Chiang and Y.-H. Hu, "Water washing effects on metals emission reduction during municipal solid waste incinerator (MSWI) fly ash melting process," Waste Management, vol. 30, no. 5, pp. 831-838, 2010.

[103] T. Mangialardi, "Disposal of MSWI fly ash through a combined washing-immobilisation process," Journal of Hazardous Materials, vol. 98, no. 1-3, pp. 225-240, 2003.

[104] Y. Xu, Y. Fu, W. Xia, D. Zhang, D. An, and G. Qian, "Municipal solid waste incineration (MSWI) fly ash washing pretreatment by biochemical effluent of landfill leachate: a potential substitute for water," Environmental Technology, vol. 39, no. 15, pp. 1949-1954, 2018.

[105] D. Yan, Z. Peng, L. Yu, Y. Sun, R. Yong, and K. Helge Karstensen, "Characterization of heavy metals and PCDD/Fs from water-washing pretreatment and a cement kiln coprocessing municipal solid waste incinerator fly ash," Waste Management, vol. 76, pp. 106-116, 2018.

[106] Z. Yang, S. Tian, R. Ji, L. Liu, X. Wang, and Z. Zhang, "Effect of water-washing on the co-removal of chlorine and heavy metals in air pollution control residue from MSW incineration," Waste Management, vol. 68, pp. 221-231, 2017.
[107] A. Ferraro, I. Farina, M. Race, F. Colangelo, R. Cioffi, and M. Fabbricino, "Pre-treatments of MSWI fly-ashes: a comprehensive review to determine optimal conditions for their reuse and/or environmentally sustainable disposal," Reviews in Environmental Science and Bio/Technology, vol. 18, no. 3, pp. 453-471, 2019.

[108] E. Loginova, M. Proskurnin, and H. J. H. Brouwers, "Municipal solid waste incineration (MSWI) fly ash composition analysis: a case study of combined chelatant-based washing treatment efficiency," Journal of Environmental Management, vol. 235, pp. 480-488, 2019.

[109] Y. Tian, R. Wang, Z. Luo et al., "Heavy metals removing from municipal solid waste incineration fly ashes by electric fieldenhanced washing," Materials, vol. 13, no. 3, 2020.

[110] S. Dontriros, S. Likitlersuang, and D. Janjaroen, "Mechanisms of chloride and sulfate removal from municipal-solidwaste-incineration fly ash (MSWI FA): effect of acid-base solutions," Waste Management, vol. 101, pp. 44-53, 2020.

[111] D. Kang, J. Son, Y. Yoo et al., "Heavy-metal reduction and solidification in municipal solid waste incineration (MSWI) fly ash using water, $\mathrm{NaOH}, \mathrm{KOH}$, and $\mathrm{NH}_{4} \mathrm{OH}$ in combination with $\mathrm{CO}_{2}$ uptake procedure," Chemical Engineering Journal, vol. 380, 2020.

[112] W. Li, Y. Sun, Y. Huang et al., "Evaluation of chemical speciation and environmental risk levels of heavy metals during varied acid corrosion conditions for raw and solidified/stabilized MSWI fly ash," Waste Management, vol. 87, pp. 407-416, 2019.

[113] H. I. Gomes, V. Funari, and R. Ferrari, "Bioleaching for resource recovery from low-grade wastes like fly and bottom ashes from municipal incinerators: a SWOT analysis," Science of the Total Environment, vol. 715, 2020.

[114] P. E. Jensen, G. M. Kirkelund, K. B. Pedersen, C. DiasFerreira, and L. M. Ottosen, "Electrodialytic upgrading of three different municipal solid waste incineration residue types with focus on $\mathrm{Cr}, \mathrm{Pb}, \mathrm{Zn}, \mathrm{Mn}, \mathrm{Mo}, \mathrm{Sb}, \mathrm{Se}, \mathrm{V}, \mathrm{Cl}$ and SO4," Electrochimica Acta, vol. 181, pp. 167-178, 2015.

[115] G. M. Kirkelund, P. E. Jensen, A. Villumsen, and L. M. Ottosen, "Test of electrodialytic upgrading of MSWI APC residue in pilot scale: focus on reduced metal and salt leaching," Journal of Applied Electrochemistry, vol. 40, no. 6, pp. 1049-1060, 2010.

[116] A. J. Pedersen, L. M. Ottosen, and A. Villumsen, "Electrodialytic removal of heavy metals from different fly ashes influence of heavy metal speciation in the ashes," Journal of Hazardous Materials, vol. 100, no. 1-3, pp. 65-78, 2003.

[117] J. B. Lund, A. Andreassen, C.-O. Ottosen, and J. M. Aaslyng, "Effect of a dynamic climate on energy consumption and production of Hibiscus rosa-sinensis L. in greenhouses," Hortscience, vol. 41, no. 2, pp. 384-388, 2006.

[118] B. Du, J. Li, W. Fang et al., "Characterization of naturally aged cement-solidified MSWI fly ash," Waste Management, vol. 80, pp. 101-111, 2018.

[119] T. Ichikawa, K. Yamada, M. Osako, and K. Haga, "Suppression of hydrogen gas evolution from cement-solidified MSWI fly ash," Journal of Advanced Concrete Technology, vol. 15, no. 10, pp. 574-578, 2017.

[120] J. Li, M. Zeng, and W. Ji, "Characteristics of the cementsolidified municipal solid waste incineration fly ash," Environmental Science and Pollution Research, vol. 25, no. 36, pp. 36736-36744, 2018.

[121] Q. Tang, Y. Zhang, Y. Gao, and F. Gu, "Use of cementchelated, solidified, municipal solid waste incinerator (MSWI) fly ash for pavement material: mechanical and 
environmental evaluations," Canadian Geotechnical Journal, vol. 54, no. 11, pp. 1553-1566, 2017.

[122] Y. Yakubu, J. Zhou, Z. Shu, Y. Zhang, W. Wang, and Y. Mbululo, "Potential application of pre-treated municipal solid waste incineration fly ash as cement supplement," Environmental Science and Pollution Research, vol. 25, no. 16, pp. 16167-16176, 2018.

[123] K. Yin, A. Ahamed, and G. Lisak, "Environmental perspectives of recycling various combustion ashes in cement production-a review," Waste Management, vol. 78, pp. 401416, 2018.

[124] X. Sun, Y. Guo, Y. Yan et al., "Co-processing of MSWI fly ash and copper smelting wastewater and the leaching behavior of the co-processing products in landfill leachate," Waste Management, vol. 95, pp. 628-635, 2019.

[125] H. Harada, M. Takaoka, K. Oshita, N. Takeda, and T. Matsumoto, "Ash-melting process utilizing thermite reaction between chromium electroplating sludge and aluminum dross," Environmental Engineering Science, vol. 22, no. 6, pp. 716-724, 2005.

[126] Y. Yue, J. Zhang, F. Sun et al., "Heavy metal leaching and distribution in glass products from the co-melting treatment of electroplating sludge and MSWI fly ash," Journal of Environmental Management, vol. 232, pp. 226-235, 2019.

[127] L. Benassi, M. Pasquali, A. Zanoletti et al., "Chemical stabilization of municipal solid waste incineration fly ash without any commercial chemicals: first pilot-plant scaling up," ACS Sustainable Chemistry \& Engineering, vol. 4, no. 10, pp. 5561-5569, 2016.

[128] W. J. Huang and J. S. Lo, "Synthesis and efficiency of a new chemical fixation agent for stabilizing MSWI fly ash," Journal of Hazardous Materials, vol. 112, no. 1-2, pp. 79-86, 2004.

[129] W. Ma, D. Chen, M. Pan et al., "Performance of chemical chelating agent stabilization and cement solidification on heavy metals in MSWI fly ash: a comparative study," Journal of Environmental Management, vol. 247, pp. 169-177, 2019.

[130] F. Huber, D. Blasenbauer, O. Mallow, J. Lederer, F. Winter, and J. Fellner, "Thermal co-treatment of combustible hazardous waste and waste incineration fly ash in a rotary kiln," Waste Management, vol. 58, pp. 181-190, 2016.

[131] F. Huber, H. Herzel, C. Adam, O. Mallow, D. Blasenbauer, and J. Fellner, "Combined disc pelletisation and thermal treatment of MSWI fly ash,” Waste Management, vol. 73, pp. 381-391, 2018.

[132] R. Li, L. Wang, T. Yang, and B. Raninger, "Investigation of MSWI fly ash melting characteristic by DSC-DTA," Waste Management, vol. 27, no. 10, pp. 1383-1392, 2007.

[133] X. Gao, B. Ji, D. Yan, Q. Huang, and X. Zhu, "A full-scale study on thermal degradation of polychlorinated dibenzop-dioxins and dibenzofurans in municipal solid waste incinerator fly ash and its secondary air pollution control in China," Waste Management \& Research, vol. 35, no. 4, pp. 437-443, 2017.

[134] D. Blasenbauer, F. Huber, J. Lederer et al., "Legal situation and current practice of waste incineration bottom ash utilisation in Europe," Waste Management, vol. 102, pp. 868$883,2020$.

[135] B. H. Cho, B. H. Nam, J. An et al., "Municipal solid waste incineration (MSWI) ashes as construction materials-a review," Materials (Basel, Switzerland), vol. 13, no. 14, 2020.

[136] P. Arjunan, M. R. Silsbee, and D. M. Della M. Roy, "Sulfoaluminate-belite cement from low-calcium fly ash and sulfur-rich and other industrial by-products," Cement and Concrete Research, vol. 29, no. 8, pp. 1305-1311, 1999.
[137] A. Heisig, T. M. Stangl, H. Hilbig et al., "Effect of alkali content of raw meal on composition and hydration of belitecalcium sulfoaluminate cement," Zkg International, vol. 69, no. 6, pp. 26-32, 2016.

[138] Y. Wang, H. Zhu, X. Jiang, G. Lv, and J. Yan, "Study on the evolution and transformation of $\mathrm{Cl}$ during $\mathrm{Co}$-incineration of a mixture of rectification residue and raw meal of a cement kiln," Waste Management, vol. 84, pp. 112-118, 2019.

[139] G. Joseph and K. Ramamurthy, "Influence of fly ash on strength and sorption characteristics of cold-bonded fly ash aggregate concrete," Construction and Building Materials, vol. 23, no. 5, pp. 1862-1870, 2009.

[140] W. Tangchirapat, C. Rattanashotinunt, R. Buranasing, and C. Jaturapitakkul, "Influence of fly ash on slump loss and strength of concrete fully incorporating recycled concrete aggregates," Journal of Materials in Civil Engineering, vol. 25, no. 2, pp. 243-251, 2013.

[141] N. U. Kockal and T. Ozturan, "Durability of lightweight concretes with lightweight fly ash aggregates," Construction and Building Materials, vol. 25, no. 3, pp. 1430-1438, 2011.

[142] S. C. Kou, C. S. Poon, and D. Chan, "Influence of fly ash as a cement addition on the hardened properties of recycled aggregate concrete," Materials and Structures, vol. 41, no. 7, pp. 1191-1201, 2008.

[143] V. Dinh Hieu, K.-S. Wang, J.-H. Chen et al., "Glass-ceramic from mixtures of bottom ash and fly ash," Waste Management, vol. 32, no. 12, pp. 2306-2314, 2012.

[144] M. Erol, A. Genç, M. L. Öveçoğlu, E. Yücelen, S. Küçükbayrak, and Y. Taptık, "Characterization of a glassceramic produced from thermal power plant fly ashes," Journal of The European Ceramic Society, vol. 20, no. 12, pp. 2209-2214, 2000.

[145] N. Lavi and Z. B. Alfassi, "The study of natural radionuclides and radon exhalation rate in ceramic materials containing fly ash developed in Israel," Radiochimica Acta, vol. 92, no. 4-6, pp. 375-378, 2004.

[146] H.-Q. Liu, G.-X. Wei, Y. Liang, and F.-Y. Dong, "Glassceramics made from arc-melting slag of waste incineration fly ash," Journal of Central South University of Technology, vol. 18, no. 6, pp. 1945-1952, 2011.

[147] H. A. Mupambwa, E. Dube, and P. N. S. Mnkeni, "Fly ash composting to improve fertiliser value-a review," South African Journal of Science, vol. 111, no. 7-8, pp. 26-31, 2015.

[148] H. Nurmesniemi, M. Mäkelä, R. Pöykiö, K. Manskinen, and O. Dahl, "Comparison of the forest fertilizer properties of ash fractions from two power plants of pulp and paper mills incinerating biomass-based fuels," Fuel Processing Technology, vol. 104, pp. 1-6, 2012.

[149] Q. Qiu and V. Hlavacek, "Energy estimation on CRN process of fly ash as a slow-release nitrogen fertilizer," Industrial \& Engineering Chemistry Research, vol. 49, no. 12, pp. 59395944, 2010.

[150] U. B. Deshannavar, M. El-Harbawi, A. Vernekar et al., "Optimization of phenol removal from aqueous solutions using fly ash obtained from power station as adsorbent: kinetic and equilibrium studies," Journal of the Indian Chemical Society, vol. 91, no. 9, pp. 1765-1773, 2014.

[151] L. Li, S. Wang, and Z. Zhu, "Geopolymeric adsorbents from fly ash for dye removal from aqueous solution," Journal of Colloid and Interface Science, vol. 300, no. 1, pp. 52-59, 2006.

[152] F. Ogata, H. Tominaga, Y. Iwata, A. Ueda, Y. Tanaka, and N. Kawasaki, "Evaluation of moisture adsorbent produced from fly ash and its adsorption ability of moisture," Kagaku Kogaku Ronbunshu, vol. 39, no. 3, pp. 231-237, 2013. 
[153] Y.-S. Shim, Y.-S. Yoo, S.-W. Rhee et al., "Evaluation of pelletized adsorbent made for removing VOCs by MSWI fly ash (II)," Eco-Materials Processing \& Design Vii, vol. 39, pp. 594-597, 2006.

[154] M. Visa, "Tailoring fly ash activated with bentonite as adsorbent for complex wastewater treatment," Applied Surface Science, vol. 263, pp. 753-762, 2012.

[155] Q. Tang, F. Gu, H. Chen et al., "Mechanical evaluation of bottom ash from municipal solid waste incineration used in roadbase," Advances in Civil Engineering, vol. 2018, 2018.

[156] H. K. Kim and H. K. Lee, "Use of power plant bottom ash as fine and coarse aggregates in high-strength concrete," Construction and Building Materials, vol. 25, no. 2, pp. 1115-1122, 2011.

[157] H. K. Kim and H. K. Lee, "Autogenous shrinkage reduction with untreated coal bottom ash for high-strength concrete," Aci Materials Journal, vol. 113, no. 3, pp. 277-285, 2016.

[158] S. B. Park, Y. I. Jang, J. Lee, and B. J. Lee, “An experimental study on the hazard assessment and mechanical properties of porous concrete utilizing coal bottom ash coarse aggregate in Korea," Journal of Hazardous Materials, vol. 166, no. 1, pp. 348-355, 2009.

[159] S. Sivakumar and B. Kameshwari, "Influence of fly ash, bottom ash, and light expanded clay aggregate on concrete," Advances in Materials Science and Engineering, vol. 2015, 2015.

[160] J. Y. Yoon, J. Y. Lee, and J. H. Kim, "Use of raw-state bottom ash for aggregates in construction materials," Journal of Material Cycles and Waste Management, vol. 21, no. 4, pp. 838-849, 2019.

[161] P. Appendino, M. Ferraris, I. Matekovits, and M. Salvo, "Production of glass-ceramic bodies from the bottom ashes of municipal solid waste incinerators," Journal of The European Ceramic Society, vol. 24, no. 5, pp. 803-810, 2004.

[162] M. F. Chong, K. P. Lee, H. J. Chieng, and I. I. Syazwani Binti Ramli, "Removal of boron from ceramic industry wastewater by adsorption-flocculation mechanism using palm oil mill boiler (POMB) bottom ash and polymer," Water Research, vol. 43, no. 13, pp. 3326-3334, 2009.

[163] D. Eliche-Quesada, M. A. Felipe-Sese, S. Martinez-Martinez et al., "Comparative study of the use of different biomass bottom ash in the manufacture of ceramic bricks," Journal of Materials in Civil Engineering, vol. 29, no. 12, 2017.

[164] G. Predeanu, L. G. Popescu, T. A. Abagiu, C. Panaitescu, B. Valentim, and A. Guedes, "Characterization of bottom ash of Pliocene lignite as ceramic composites raw material by petrographic, SEM/EDS and Raman microspectroscopical methods," International Journal of Coal Geology, vol. 168, pp. 131-145, 2016.

[165] J. Maria Terrones-Saeta, J. Suarez-Macias, F. Javier IglesiasGodino et al., "Study of the incorporation of biomass bottom ashes in ceramic materials for the manufacture of bricks and evaluation of their leachates," Materials, vol. 13, no. 9, 2020.

[166] S. Kumar and J. Stewart, "Utilization of Illinois PCC dry bottom ash for compacted landfill barriers," Soil and Sediment Contamination: An International Journal, vol. 12, no. 3 , pp. 401-415, 2003.

[167] J. Yao, Q. Kong, W. Li, H. Zhu, and D. Shen, "Effect of leachate recirculation on the migration of copper and zinc in municipal solid waste and municipal solid waste incineration bottom ash co-disposed landfill," Journal of Material Cycles and Waste Management, vol. 16, no. 4, pp. 775-783, 2014.

[168] J. Yao, Z. Qiu, Q. Kong et al., "Migration of $\mathrm{Cu}, \mathrm{Zn}$ and $\mathrm{Cr}$ through municipal solid waste incinerator bottom ash layer in the simulated landfill," Ecological Engineering, vol. 102, pp. 577-582, 2017.

[169] J.-Z. Yang, Y. Yang, Y. Li et al., "Leaching of metals from asphalt pavement incorporating municipal solid waste incineration fly ash," Environmental Science and Pollution Research, vol. 25, no. 27, pp. 27106-27111, 2018.

[170] Y. Zhu, Y. Zhao, C. Zhao, and R. Gupta, "Physicochemical characterization and heavy metals leaching potential of municipal solid waste incinerated bottom ash (MSWI-BA) when utilized in road construction," Environmental Science and Pollution Research, vol. 27, no. 12, pp. 14184-14197, 2020.

[171] E. Romeo, L. Mantovani, M. Tribaudino et al., "Reuse of stabilized municipal solid waste incinerator fly ash in asphalt mixtures," Journal of Materials in Civil Engineering, vol. 30, no. 8, 2018.

[172] Y. Xue, H. Hou, S. Zhu, and J. Zha, "Utilization of municipal solid waste incineration ash in stone mastic asphalt mixture: pavement performance and environmental impact," Construction and Building Materials, vol. 23, no. 2, pp. 989-996, 2009.

[173] A. Al-Hdabi, H. A. Nageim, F. Ruddock, and L. Seton, "Laboratory studies to investigate the properties of novel cold-rolled asphalt containing cement and waste bottom ash," Road Materials and Pavement Design, vol. 15, no. 1, pp. 78-89, 2014.

[174] J.-S. Chen, P.-Y. Chu, J.-E. Chang, H.-C. Lu, Z.-H. Wu, and K.-Y. Lin, "Engineering and environmental characterization of municipal solid waste bottom ash as an aggregate substitute utilized for asphalt concrete," Journal of Materials in Civil Engineering, vol. 20, no. 6, pp. 432-439, 2008.

[175] C. K. Estakhri and D. Saylak, "Sulfur-modified bottom ash as aggregate in hot-mix asphalt concrete-field demonstration project," Trb Distinguished Lecture, Pt 1-Asphalt Mixtures, Pt 2: Materials and Construction, vol. 20, pp. 57-65, 2000.

[176] S. W. Goh and Z. You, "A preliminary study of the mechanical properties of asphalt mixture containing bottom ash," Canadian Journal of Civil Engineering, vol. 35, no. 10, pp. 1114-1119, 2008.

[177] M. M. Hassan and H. A. Khalid, "Fracture characteristics of asphalt mixtures containing incinerator bottom ash aggregate," Transportation Research Record, vol. 2180, pp. 1-8, 2010.

[178] C.-M. Huang, C.-T. Chiu, K.-C. Li, and W.-F. Yang, "Physical and environmental properties of asphalt mixtures containing incinerator bottom ash," Journal of Hazardous Materials, vol. 137, no. 3, pp. 1742-1749, 2006.

[179] H.-L. Luo, S.-H. Chen, D.-F. Lin, and X.-R. Cai, "Use of incinerator bottom ash in open-graded asphalt concrete," Construction and Building Materials, vol. 149, pp. 497-506, 2017.

[180] M. Pasetto and N. Baldo, "Laboratory investigation on foamed bitumen bound mixtures made with steel slag, foundry sand, bottom ash and reclaimed asphalt pavement," Road Materials and Pavement Design, vol. 13, no. 4, pp. 691-712, 2012.

[181] K. M. Tasneem, J. Eun, and B. Nam, "Leaching behaviour of municipal solid waste incineration bottom ash mixed with Hot-Mix Asphalt and Portland cement concrete used as road construction materials," Road Materials and Pavement Design, vol. 18, no. 3, pp. 687-712, 2017.

[182] A. Vaitkus, J. Gražulyte, O. Šernas, V. Vorobjovas, and R. Kleiziene, "An algorithm for the use of MSWI bottom ash as a building material in road pavement structural layers," 
Construction and Building Materials, vol. 212, pp. 456-466, 2019.

[183] Y. Yuan, X. Zhu, L. Li et al., "Effect of the interfacial zone on the tensile-damage behavior of an asphalt mixture containing MSWI bottom ash aggregates," Journal of Materials in Civil Engineering, vol. 29, no. 4, 2017.

[184] M. L. Zeng, K. Ksaibati, and T. R. B. Trb, "Evaluation of moisture susceptibility of asphalt mixtures containing bottom ash," Bituminous Paving Mixtures 2003: Materials and Construction, vol. 29, pp. 25-33, 2003.

[185] X. S. Zhang, D. Gress, S. Karpinski et al., "Utilization of municipal solid waste combustion bottom ash as a paving material," Operations and Safety, vol. 29, pp. 257-263, 1999.

[186] S. Asal, S. J. Laux, M. C. McVay, and T. G. Townsend, "Blending organic material with municipal solid waste incinerator bottom ash to promote in-situ carbonation in road base," Waste Management \& Research, vol. 37, no. 9, pp. 951-955, 2019.

[187] A. Mandal, B. R. Paramkusam, and O. Sinha, "Fluidized bed combustion bottom ash: a better and alternative geo-material resource for construction," Waste Management \& Research, vol. 36, no. 4, pp. 351-360, 2018.

[188] M. L. Schafer, K. A. Clavier, T. G. Townsend, R. Kari, and R. F. Worobel, "Assessment of the total content and leaching behavior of blends of incinerator bottom ash and natural aggregates in view of their utilization as road base construction material," Waste Management, vol. 98, pp. 92-101, 2019.

[189] R. D. Vallezermeno, J. Formosa, M. Prieto et al., "Pilot-scale road subbase made with granular material formulated with MSWI bottom ash and stabilized APC fly ash: environmental impact assessment," Journal of Hazardous Materials, vol. 266, pp. 132-140, 2014.

[190] R. Xie, Y. Xu, M. Huang, H. Zhu, and F. Chu, “Assessment of municipal solid waste incineration bottom ash as a potential road material," Road Materials and Pavement Design, vol. 18, no. 4, pp. 992-998, 2017.

[191] Y. Huang, J. Chen, S. Shi et al., "Mechanical properties of municipal solid waste incinerator (MSWI) bottom ash as alternatives of subgrade materials," Advances in Civil Engineering, vol. 2020, 2020.

[192] Y. Zhou, L. Pan, Q. Tang et al., "Evaluation of carbonation effects on cement-solidified contaminated soil used in road subgrade," Advances in Materials Science and Engineering, vol. 2018, 2018.

[193] I. Vegas, J. A. Ibañez, J. T. San José, and A. Urzelai, "Construction demolition wastes, Waelz slag and MSWI bottom ash: a comparative technical analysis as material for road construction," Waste Management, vol. 28, no. 3, pp. 565-574, 2008.

[194] D. Song, L. Dong, and X. Feng, "Approach to the application of ultrasonic technology to measuring physical properties of new building materials," Indian Journal of Geo-Marine Sciences, vol. 48, no. 5, pp. 739-746, 2019.

[195] P. Flyhammar and D. Bendz, "Leaching of different elements from subbase layers of alternative aggregates in pavement constructions," Journal of Hazardous Materials, vol. 137, no. 1, pp. 603-611, 2006. 